
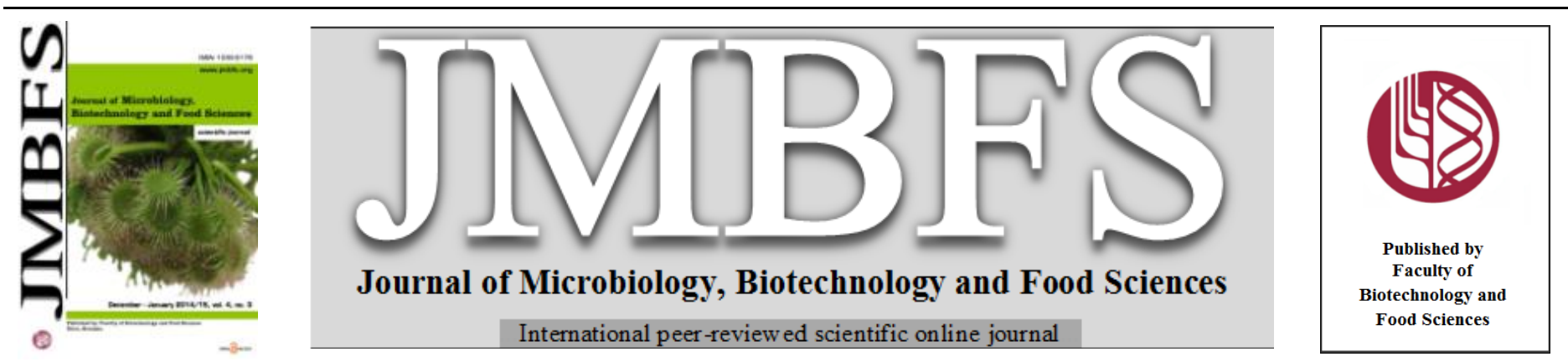

\title{
CHEMICAL STABILITY OF COTTONSEED AND GROUNDNUT OIL USED FOR FRYING BHAJIAS AND ITS SENSORY QUALITIES
}

\author{
Ashima Gupta* and Mini Sheth
}

Address(es): Faculty of Family and Community Sciences, The Maharaja Sayajirao University of Baroda, Vadodara-390002,Gujarat, India.

*Corresponding author: ashimafoodee@gmail.com

doi: $10.15414 / j m b f s .2014-15.4 .3 .198-202$

\section{ARTICLE INFO}

Received 7. 6. 2014

Revised 22. 9. 2014

Accepted 25. 9. 2014

Published 1. 12. 2014

Regular article

OPEN $\partial_{\text {ACCESS }}$

\begin{abstract}
Deep fried snacks, which evolved as snacks between meals include bhajia, samosa, etc are very popular in India and commercially exploited on a wide scale.Cottonseed and Groundnut oil frequently used in Gujarat for cooking purpose studied for its intermittent frying stability. Indian fried snack popularly known as 'Bhajia' fried for $5 \mathrm{~min}$ at an interval of $1 \mathrm{~h} ; 5$ times a day for 5 consecutive days and studied for its various sensory attributes using 9-point hedonic scale. Standard AOCS and AOAC methods were used to determine the quality of oil. Peroxide and $\mathrm{p}$-anisidine values of both oils increased significantly $\mathrm{p}<0.001$ during the $25 \mathrm{~h}$ of intermittent frying. Iodine value of cottonseed oil did not decrease throughout the intermittent frying period. Polar components increased 257.5\% in cottonseed oil (CSO) and $142.9 \%$ in groundnut oil (GNO). The saturated and monounsaturated fatty acid content increased significantly with the increase in frying hours.No significant change was seen in linoleic/palmitic acid ratio of both the oils during bhajias frying. The sensory qualities of bhajia fried at different intervals did not change significantly for various attributes namely flavor, taste, crispness, greasiness, odor, color, appearance and overall acceptability.
\end{abstract}

Keywords: Edible oil, bhajia, frying, fatty acid profile, oxidation, sensory quality

\section{INTRODUCTION}

The popularity of foodstuffs covered with tempura-type frying battered products has increased worldwide (Patton, 2011). In this type of food, a chemically leavened batter serves as the outer coating of the food piece; giving good visual and structural characteristics to the product (Loewe, 1993). Popularity and simultaneous increase in demand of these products amongst the consumers ensure good sensory acceptability of battered foods. The deep fried snacks, which evolved as snacks between meals in India, have been known over a period of time, and are commercially exploited on a wide scale. These include a variety of foods including bhajia, samosa, bread rolls etc. Many existing studies on frying batters mainly analyze the characteristic of the basic ingredient, wheat flour for their sensory qualities (Cunningham et al., 1981; Hsia et al., 1992).

Deep-fat frying is a popular method employed in cooking various culinary preparations. This process may be defined as cooking by immersion of food in edible oil or fat at a temperature above the boiling point of water (Hubbardet al., 2000). During frying, the material undergoes chemical and physical transformation at a high operating temperature range of $160-180^{\circ} \mathrm{C}$. The process starts with frying the raw product followed by starch gelatinization, protein denaturation, aromatizing and coloring via maillard reactions and finally leading to dehydration (Ziaiifar $\boldsymbol{e t}$ al., 2008). Repeated series of frying at elevated temperature may lead to undesired degraded reactions and decomposed constituents which results in oxidative rancidity; and/or hydrolysis and formation of polymerized and polar compounds and trans fats. Particles of food materials, as well as particles from breaded or battered food surface coatings, contaminate the frying oil in fairly large quantities. These particles remain in the frying oil until they are caramelized and finally become charred to fine suspending particles of black carbon. This is an important factor contributing to the darkening of the oil.

Deep fat frying imparts good taste, flavor, pleasing golden brown color, and crisp texture to food products along with excellent mouth feel. Number of studies on the modifications of fats and oils during heating and frying under very different conditions has been carried out on the assumption that acceptability of fried foods depends on the quality of the used frying oil or fat (Paul et al., 1997). Deteriorated oils are not only insidious causes of cancers, hypertension and coronary heart diseases but also result in foods with poor texture, flavor and shelf stability (Saguy et al., 2002).

The broad objective of this study was to investigate the intermittent frying stability of groundnut and cottonseed oil used for frying bhajias, in terms of its breakdown products. Consequentially to assess the sensory quality of bhajias fried in these oils.

\section{MATERIAL AND METHODS}

\section{Procurement of raw material}

Double filtered groundnut oil (GNO) and refined cottonseed oil (CSO) were used for frying within one month of manufacture, procured from Ankur Oil Industries (Ahmedabad). For the preparation of bhajias Bengal gram flour (Gaaya) and other ingredients like sodium bicarbonate (Tata), salt (Tata), turmeric powder, red chilli powder and bishop seeds were purchased from local market. Potatoes of Kufri Surya variety were procured from Potato Research Station, Deesa (Gujarat).

\section{Preparation of batter for Bhajia}

Bhajias were prepared by deep frying thinly sliced circular potatoes that were dipped in a batter prepared out of $75 \mathrm{~g}$ Bengal gram flour with $70 \mathrm{ml}$ water, a pinch of sodium bicarbonate, salt to taste, $1 / 4$ tsp turmeric powder, $1 / 4$ tsp red chilli powder and $1 / 2$ tsp bishop seeds were added to the batter (Pasricha, 2004).

\section{Frying procedure and sampling of fried oil}

Frying experiment was performed in triplicates. Frying was conducted in 2-L capacity hindalium domestic deep frying pans (diameter-12", depth-7.2"). Mitsubishi (ISI) mark auto ignition stainless steel LPG Stove was used during entire frying experiments. 1.5 $\mathrm{L}$ GNO and CSO were placed in separate deep frying pans and heated at $180^{\circ} \mathrm{C}$ for each frying. Batches of bhajias were fried for $5 \mathrm{~min}$ at an interval of $1 \mathrm{~h}$; five times a day for 5 consecutive days. The frying temperature was monitored after every minute with the help of mercury thermometer. Frying pans were not covered during the frying experiment. Oils were not topped up during frying. At the end of each day an aliquot of cooled 75 $\mathrm{ml}$ oil was pipette out from each fryer, stored in amber color glass air tight bottles and kept at $-4^{0} \mathrm{C}$ in a deep freezer for further analysis. 


\section{Analytical Methods}

Fatty acid methyl esters were prepared according to the analytical method of AOAC 996.01 (AOAC, 1995). Fatty acid composition was determined at 0,5 , and $10 \mathrm{~h}$ interval. GC (NUCON-5765) with $30 \mathrm{~m} \times 0.25 \mathrm{~mm}$ id, $0.2 \mu \mathrm{m}$ film, nonbonded $90 \%$ cyanopropyl, $10 \%$ phenyl siloxane capillary column with flame ionization detector was used for determination of fatty acids. Operating conditions: injector temperature $250^{\circ} \mathrm{C}$, detector temperature was adjusted at $275^{\circ} \mathrm{C}$, hydrogen flow $34 \mathrm{ml} / \mathrm{min}$, air flow ca $300 \mathrm{ml} / \mathrm{min}$, split ratio was $100: 1$. Helium as a carrier gas with flow rate of $21 \mathrm{~cm} / \mathrm{s}$ at $175^{\circ} \mathrm{C}$ was adjusted. Initia oven temperature was adjusted to $120^{\circ} \mathrm{C}$ hold for $4 \mathrm{~min}$ and increased up to $230^{\circ} \mathrm{C}$. Standard methyl esters of fatty acids were used as authentic samples and peak identification for samples was done by comparing relative retention times.

Total Polar Components (TPC) was determined by gravimetric method at 0,5 and $10 \mathrm{~h}$ interval. TPC were determined after column chromatography separation of non-polar fraction. Peroxide value (PV), Iodine value (IV), Refractive Index (RI), Acid value (AV), p-anisidine (p-AV), and Color determined at 0, 5, 10, 15, 20, $25 \mathrm{~h}$ interval. PV was evaluated following titration method. PV was expressed as milliequivalents of active oxygen per kilogram of oil (meq $\mathrm{O}_{2} / \mathrm{kg}$ ) The IV of the samples was determined as Wij's method. RI was determined using Abbe refractometer (ATAGO DR-A1, US). Readings were taken at $40^{\circ} \mathrm{C}$ temperature was regulated by using steam circulation (AOAC, 1995).

$\mathrm{AV}$ was defined as the number of milligrams of potassium hydroxide required to neutralize the free fatty acids present in one gram of fat. $\mathrm{p}-\mathrm{AV}$ value was determined as the secondary oxidation products of the oil. Absorbance was measured at $350 \mathrm{~nm}$, using Shimadzu $1201 \mathrm{UV}$-VIS spectrophotometer. The totox (total oxidation products) value used for evaluation of oils was calculated as: $T V=2 P V+p-A V$. PV was multiplied by a factor 2 because it has more pronounced effect on the stability of refined oil. Color was determined by Lovibond Tintometer (model F). Oil sample color was matched by adjusting yellow $(\mathrm{Y})$ and red $(\mathrm{R})$ racks of the instrument in the ratio of $\mathrm{Y}+5 \mathrm{R}$. A glass cell was filled with the sample and placed inside the illuminated cabinet (AOCS, 1998)

\section{Sensory evaluation}

Sensoryevaluation of Bhajias was carried out at $0,6,11,16$ and $21 \mathrm{~h}$ of intermittent frying. 25 semi trained sensory panelists who were normally familiar with the quality of bhajias were selected for sensory evaluation. Bhajias were judged for appearance, color, crispness, greasiness, flavor, odor, and overall acceptability. Bhajias were evaluated on 9-point hedonic scale where, 9-like extremely, 8-like very much, 7-like moderately, 6-like slightly, 5-neither like nor dislike, 4- dislike slightly, 3-dislike moderately, 2-dislike very much, 1-dislike extremely (Joshi, 2006).

\section{Oil uptake by bhajias during $25 \mathrm{~h}$ of intermittent frying}

Oil uptake was measured by taking difference between the initial and total amount of oil (CSO and GNO) left after $25 \mathrm{~h}$ of intermittent frying.

\section{Oil uptake= Initial amount of oil-Total oil left in fryer after $25 \mathrm{~h}$ of} intermittent frying

\section{Statistical analysis}

Mean and standard deviation (SD) of duplicate values obtained after conducting the experiments in triplicate were calculated using Microsoft Excel 2007. Analysis of variance (ANOVA) was used to determine significant difference amongst the fried samples at different intervals of frying for chemical and sensory quality. Student' $t$ ' test was used to find the significant difference between the two means.

\section{RESULTS AND DISCUSSION}

\section{Fatty acid profile}

Fatty acid profile of fried CSO and GNO is shown in Table 1 and 2 respectively. The saturated fatty acid content of CSO and GNO increased significantly $(\mathrm{p}<0.001)$ with the increase in frying hours. Myristic acid increased from $0.95 \%$ to $1.03 \%$ in CSO fried intermittently up to $10 \mathrm{~h}$. Palmitic acid increased up to $4.28 \%$ and $1 \%$ in CSO and GNO respectively. At $10 \mathrm{~h}$ of intermittent frying GNO showed $9.77 \%$ increase in stearic acid. However, stearic acid in CSO decreased significantly $(\mathrm{p}<0.001)$ when bhajias were intermittently fried up to 10 $\mathrm{h}$. GNO rich in oleic acid showed significant $(\mathrm{p}<0.001)$ increase of $2.24 \%$ at $10 \mathrm{~h}$ duration. However, oleic acid in CSO increased only $0.05 \%$ at $10 \mathrm{~h}$ of frying duration. The polyunsaturated fatty acid (linoleic acid) of CSO and GNO was decreased by $2.99 \%$ and $11.18 \%$ respectively at $10 \mathrm{~h}$ of intermittent frying.Hazuka et al. (2000) reported no significant differences in loss of unsaturated fatty acids were observed between the frying medium and the extracted fat for liquid and partially hydrogenated rapeseed oils when potato fritters were fried for 9 days. 17\% increase in oleic acid was observed when potato fritters were fried for $9 \mathrm{~h}$. Moreover, 23\% decrease in linoleic acid was reported in both oils. Studies have reported change in fatty acid profile of frying oils that may have changed because of cyclization, polymerization, and pyrolytic, oxidative, hydrolytic and other chemical changes promoted by frying conditions (Vasishtha et al., 1996)

$\underline{\text { Table 1Fatty acid profile (g/100 g fat) of CSO at different intervals }}$

\begin{tabular}{|c|c|c|c|c|}
\hline \multirow{2}{*}{ Fatty acid } & \multicolumn{3}{|c|}{ Hours } & \multirow[t]{2}{*}{ F-value } \\
\hline & $\mathbf{O} \mathbf{h}$ & $5 \mathrm{~h}$ & $10 \mathrm{~h}$ & \\
\hline $\begin{array}{l}\text { Myristic } \\
(14: 0)\end{array}$ & $0.95 \pm 0.01^{\mathrm{a}}$ & $0.99 \pm 0.02^{\mathrm{a}}$ & $1.03 \pm 0^{\mathrm{b}}$ & $24.79 * * *$ \\
\hline $\begin{array}{l}\text { Palmitic } \\
(16: 0)\end{array}$ & $25.23 \pm 0.02^{\mathrm{a}}$ & $25.46 \pm 0.45^{\mathrm{b}}$ & $26.31 \pm 0.27^{\mathrm{c}}$ & $7.08 * * *$ \\
\hline $\begin{array}{l}\text { Plamitoleic } \\
(16: 1)\end{array}$ & $0.65 \pm 0.02^{\mathrm{a}}$ & $0.65 \pm 0^{\mathrm{a}}$ & $0.73 \pm 0.04^{\mathrm{b}}$ & $6.24 * * *$ \\
\hline $\begin{array}{l}\text { Stearic } \\
(18: 0)\end{array}$ & $2.86 \pm 0.01^{\mathrm{a}}$ & $2.76 \pm 0.06^{\mathrm{b}}$ & $2.59 \pm 0.04^{\mathrm{c}}$ & $20.99 * * *$ \\
\hline Oleic (18:1) & $19.67 \pm 0.05$ & $19.74 \pm 0.07$ & $19.68 \pm 0.02$ & $0.74^{\mathrm{NS}}$ \\
\hline $\begin{array}{l}\text { Linoleic } \\
(18: 2)\end{array}$ & $50.51 \pm 0.71^{\mathrm{a}}$ & $48.90 \pm 0.49^{b}$ & $49.04 \pm 0.69^{b}$ & $3.97 * * *$ \\
\hline $\begin{array}{l}\text { Linolenic } \\
(18: 3)\end{array}$ & - & $0.09 \pm 0$ & - & - \\
\hline $\begin{array}{l}\text { Arachidic } \\
(20: 4)\end{array}$ & $0.52 \pm 0.01^{\mathrm{a}}$ & $0.54 \pm 0.03^{b}$ & $0.33 \pm 0.01^{\mathrm{c}}$ & $76.22 * * * *$ \\
\hline $\begin{array}{l}\text { Behenic } \\
(22: 0)\end{array}$ & $0.17 \pm 0.01$ & $0.16 \pm 0$ & - & - \\
\hline
\end{tabular}

Note:Mean \pm standard deviation (SD); *, $\mathrm{p}<0.05, * *, \mathrm{p}<0.01, * * *, \mathrm{p}<0.001 ;$ CSO-Cottonseed oil; Similar superscripts in each row indicate no significant difference at $\mathrm{p}<0.05$.

Table 2Fatty acid profile ( $\mathrm{g} / 100 \mathrm{~g}$ fat) of GNO at different intervals

\begin{tabular}{|c|c|c|c|c|}
\hline \multirow{2}{*}{ Fatty acid } & \multicolumn{3}{|c|}{ Hours } & \multirow[t]{2}{*}{ F-value } \\
\hline & $\mathbf{0 h}$ & $5 \mathrm{~h}$ & $10 \mathrm{~h}$ & \\
\hline $\begin{array}{l}\text { Palmitic } \\
(16: 0)\end{array}$ & $10.91 \pm 0.60^{\mathrm{a}}$ & $10.25 \pm 0.53^{b}$ & $11.02 \pm 0.39^{\mathrm{a}}$ & $1.30 * * *$ \\
\hline $\begin{array}{l}\text { Stearic } \\
(18: 0)\end{array}$ & $3.07 \pm 0.09^{\mathrm{a}}$ & $3.23 \pm 0.03^{\mathrm{b}}$ & $3.37 \pm 0.08^{\mathrm{c}}$ & $9.49 * * *$ \\
\hline Oleic (18:1) & $59.40 \pm 0.09^{\mathrm{a}}$ & $59.76 \pm 0.12^{\mathrm{b}}$ & $60.73 \pm 0.47^{\mathrm{c}}$ & $11.67 * * *$ \\
\hline $\begin{array}{l}\text { Linoleic } \\
(18: 2)\end{array}$ & $22.48 \pm 0.18^{\mathrm{a}}$ & $20.91 \pm 0.17^{b}$ & $20.21 \pm 0.48^{\mathrm{c}}$ & $27.72 * * *$ \\
\hline $\begin{array}{l}\text { Arachidic } \\
(20: 4)\end{array}$ & $1.41 \pm 0.01^{\mathrm{a}}$ & $1.46 \pm 0.07^{\mathrm{b}}$ & $1.31 \pm 0.06^{\mathrm{c}}$ & $4.55 * * *$ \\
\hline $\begin{array}{l}\text { Behenic } \\
(22: 0)\end{array}$ & $1.45 \pm 0.14^{\mathrm{a}}$ & $2.20 \pm 0^{\mathrm{b}}$ & $2.11 \pm 0.03^{\mathrm{c}}$ & $1.44 * * *$ \\
\hline
\end{tabular}

Note:Mean \pm standard deviation (SD); ${ }^{*}, \mathrm{p}<0.05,{ }^{* *}, \mathrm{p}<0.01,{ }^{* * *}, \mathrm{p}<0.001$; GNO-Groundnut oil; Similar superscripts in each row indicate no significant difference at $\mathrm{p}<0.05$

\section{Peroxide value}

Table 3 shows the peroxide value (PV) of GNO and CSO at different intervals of intermittent frying. Primary oxidation in cottonseed oil showed significant higher $(\mathrm{p}<0.001)$ values when compared with suggested PFAlimit i.e. $<10 \mathrm{meq} \mathrm{O} / \mathrm{kg}$ than groundnut oil at $0 \mathrm{~h}$ (PFA, 2007). At $5 \mathrm{~h}$ of intermittent frying $56.6 \%$ increase in PV of GNO was observed. However, CSO showed 34\% decrease in peroxide value at $5 \mathrm{~h}$ of intermittent frying. CSO showed a progressive decrease by $50.3 \%$ in PV up to $15 \mathrm{~h}$ of frying. Study by Rani et al [16] reported that PV of sunflower oil increased from 2.0 to 28.65 after $22 \mathrm{~h}$ of discontinuous frying and then started decreasing thereafter. Despite increase at $5 \mathrm{~h}$ of intermittent frying in PV of GNO, it decreased significantly $(\mathrm{p}<0.001)$ at $10 \mathrm{~h}$ of intermittent frying. In the present study, peroxide values of oils showed rise and fall as the duration of frying increased. Indication of instability of peroxides is reported by other studies who stated parallel results when various vegetable oils were used for frying. Use of PV for following the oxidative deterioration of fats and oils during deep-frying is problematic because peroxides are destroyed by heating temperature and during cooling new peroxides are formed (Rani et al., 2010; Faroosh et al., 2009; Augustin et al., 1983).

\section{p-anisidine value}

The secondary decomposition products assessed by p-anisidine (p-AV) are shown in Table 3. At $0 \mathrm{~h}$ the $\mathrm{p}$-anisidine value of GNO and CSO was 0.58 and 8.71. However, CSO p-AV at $0 \mathrm{~h}$ was beyond the approved limit of 2 for fresh oils (Singhal et al., 2008). p-AV of GNO and CSO showed significant ( $\mathrm{p}<0.001$ ) increase from 61.53 to 82.64 and 62.09 to 85.47 respectively at 5 and $10 \mathrm{~h}$ of intermittent bhajia frying. Frying of cod fillets showed an increase of 83.7 units during first 5 days and thereafter increase ranged from 68.5 to 86.5 during subsequent days of frying in refined rapeseed oil (Tynek et al., 2001). p-AV mainly accounts as degradation products of peroxides rose significantly $(\mathrm{p}<0.001)$ to 91.9 and 109.2 in GNO and CSO respectively at $15 \mathrm{~h}$ of frying 
interval, which continued to increase up to $25 \mathrm{~h}$ of intermittent frying. Further, when potato fritters were fried in refined rapeseed oil for continuous 9 days (15 cycles each day), p-AV increased from 3.8 to 186 (Hazuka et al., 2000).

\section{Acid value}

Acid value $(\mathrm{AV})$ of GNO oil at $0 \mathrm{~h}$ was significantly $(\mathrm{p}<0.001)$ high because of different grades viz. filtered (GNO) and refined (CSO). However, significant increase in $\mathrm{AV}$ of $\mathrm{CSO}$ was noticed at $5 \mathrm{~h}$ of intermittent frying (Table 3). According to PFA, suggested AV for GNO was $<6 \mathrm{mg} \mathrm{KOH} / \mathrm{g}$ and $0.5 \mathrm{mg}$ $\mathrm{KOH} / \mathrm{g}$ for CSO (PFA, 2007). During frying increase in this parameter is used to assess hydrolytic degradation in oils. GNO at $10 \mathrm{~h}$ of intermittent frying showed $24.35 \%$ increase in AV however; CSO showed two folds increase as compared to GNO. Refined rapeseed oil used for frying cod fillets, AV showed 1.64 units increase after $6.2 \mathrm{~h}$ of intermittent frying (Tynek et al., 2001). After 5 days (25 h) of bhajia frying significant $(\mathrm{p}<0.001)$ increase in AV with frying time was observed in both the oils. In some countries of the European Union (EU) AV greater than 2.5 disqualifies the oil for any further use (Firestone, 1993). However, in the present study none of the oils reached the discarding limit set by EU.

\section{Iodine value}

It was found that iodine value (IV) of CSO altered significantly $(\mathrm{p}<0.05)$ after 5 days of intermittent frying, indicating decrease in unsaturated fatty acids shown in Table 3. However, bhajia frying in GNO showed no significant change after $25 \mathrm{~h}$ of intermittent frying. Reduction in IV is due to complex series of chemical reactions characterized by a decrease in the total unsaturated content of the oil due to abstraction of hydrogen adjacent to the double bond, oxidation, scission, and polymerization (Tyagi et al., 2001; Narasimhamurthy et al., 1998).

\section{Refractive Index}

The refractive index (RI) of fried oils is reported in Table 3. RI recommended by PFA in GNO was 1.4620-1.4640 and in CSO was $1.4630-1.4660$ (PFA, 2007) The RI of GNO and CSO at $0 \mathrm{~h}$ was 1.4624 and 1.4641 respectively. Refractive index of both the oils increased significantly $(\mathrm{p}<0.001)$ at the end of $25 \mathrm{~h}$ of intermittent frying. In another study similar pattern was observed when pooris were fried in blend of cottonseed and mustard oil (Premavalli et al., 1998). Both oils were within the recommended limit at the end of $25 \mathrm{~h}$ of intermittent frying. Color

Change in red and yellow color of fried oil is shown in Table 3.ANOVA analysis indicated significant increase in red and yellow color in both the oils during $25 \mathrm{~h}$ of intermittent frying.Student ' $\mathrm{t}$ ' showed significant $(\mathrm{p}<0.05)$ increase in yellow and red color of both the oils up to $5 \mathrm{~h}$ ofbhajia frying duration. In a study by Rani et al. (2010) reported fat become darker at the end of $24 \mathrm{~h}$ of heating. Increase in color of both the oils was noticed up to $25 \mathrm{~h}$ of intermittent frying. In a study by Ogunsina et al.(2011) showed 52\% increase in color intensity of refined groundnut oil when potato slices were fried in 10 repeated successions spanning a total time of $2 \mathrm{~h}$. Rise in color intensity of fried oils is indicative of increase in its oxidation (redder the oil, the more oxidized it is) thus reducing its stability (Hack et al., 2009).

Table 3 Changes in chemical and physical characteristics of frying oil at intermittent intervals

\begin{tabular}{|c|c|c|c|c|c|c|c|c|}
\hline $\begin{array}{l}\text { Chemical } \\
\text { Parameter }\end{array}$ & Oil & \multicolumn{7}{|c|}{ Duration of frying (hours) } \\
\hline $\begin{array}{l}\text { Peroxide } \\
\text { value } \\
\left(\text { meq } \mathrm{O}_{2} / \mathrm{kg}\right)\end{array}$ & CSO & $13.85 \pm 0.40^{\mathrm{a}}$ & $9.13 \pm 0.62^{b}$ & $8.1 \pm 0.08^{\mathrm{c}}$ & $6.88 \pm 0.49^{\mathrm{d}}$ & $7.2 \pm 0.48^{\mathrm{d}}$ & $10.38 \pm 0.15^{\mathrm{e}}$ & $155.48 * * *$ \\
\hline \multirow{2}{*}{$\begin{array}{l}\text { p-anisidine } \\
\text { value }\end{array}$} & CSO & $8.71 \pm 0.27^{\mathrm{a}}$ & $62.09 \pm 0.64^{\mathrm{b}}$ & $85.47 \pm 3.53^{\mathrm{c}}$ & $109.22 \pm 1.74^{\mathrm{d}}$ & $123.18 \pm 3.17^{\mathrm{e}}$ & $129.87 \pm 4.28^{\mathrm{f}}$ & $1125.62 * * *$ \\
\hline & GNO & $0.58 \pm 0.28^{\mathrm{a}}$ & $61.53 \pm 1.42^{\mathrm{b}}$ & $82.64 \pm 3.32^{\mathrm{c}}$ & $91.92 \pm 1.09^{\mathrm{d}}$ & $95.64 \pm 0.77^{\mathrm{e}}$ & $108.82 \pm 2.14^{f}$ & $1879.97 * * *$ \\
\hline $\begin{array}{l}\text { Iodine value } \\
\left(\mathrm{mg} \mathrm{I}_{2} / \mathrm{g}\right)\end{array}$ & CSO & $98.76 \pm 0.16^{\mathrm{a,c}}$ & $101.34 \pm 4.19^{\mathrm{a}}$ & $100.89 \pm 4.86^{\mathrm{a}}$ & $99.21 \pm 3.10^{\mathrm{a}}$ & $104.99 \pm 0.66^{\mathrm{a,b}}$ & $104.3 \pm 1.57^{\mathrm{a}, \mathrm{b}}$ & $2.96 *$ \\
\hline $\begin{array}{l}\text { Acid value } \\
\text { (mg KOH/g) }\end{array}$ & GNO & $0.78 \pm 0.07^{\mathrm{a}}$ & $0.85 \pm 0.04^{\mathrm{a}}$ & $0.97 \pm 0.01^{\mathrm{b}}$ & $1.04 \pm 0.02^{\mathrm{c}}$ & $1.22 \pm 0.5^{\mathrm{d}}$ & $1.29 \pm 0.06^{\mathrm{d}}$ & $74.87 * * *$ \\
\hline \multicolumn{9}{|c|}{ Physical parameters } \\
\hline \multirow{2}{*}{$\begin{array}{l}\text { Color (Y) } \\
\text { Yellow }\end{array}$} & CSO & $2.18 \pm 0.24^{\mathrm{a}}$ & $3.9 \pm 0.12^{\mathrm{b}}$ & $6.03 \pm 0.51^{\mathrm{c}}$ & $7.03 \pm 0.64^{\mathrm{c}, \mathrm{d}}$ & $7.55 \pm 0.70^{\mathrm{d}}$ & $9.13 \pm 0.19^{\mathrm{e}}$ & $120.95 * * *$ \\
\hline & GNO & $3.4 \pm 0.08^{\mathrm{a}}$ & $4.03 \pm 0.40^{\mathrm{b}}$ & $4.53 \pm 0.13^{\mathrm{c}}$ & $5.3 \pm 0.24^{\mathrm{d}}$ & $6.98 \pm 0.35^{\mathrm{e}}$ & $7.85 \pm 0.37^{f}$ & 144.06 *** \\
\hline \multirow{2}{*}{$\begin{array}{l}\text { Color }(\mathbf{R}) \\
\text { Red }\end{array}$} & CSO & $1.63 \pm 0.05^{\mathrm{a}}$ & $2.50 \pm 1^{\mathrm{a}, \mathrm{b}}$ & $3.25 \pm 0.29^{b}$ & $5 \pm 0^{\mathrm{c}}$ & $6.38 \pm 0.29^{\mathrm{c}}$ & $14.25 \pm 2.87^{\mathrm{d}}$ & $44.68 * * *$ \\
\hline & GNO & $1.88 \pm 0.25^{\mathrm{a}}$ & $4.53 \pm 1.68^{b}$ & $5.58 \pm 0.05^{\mathrm{b}}$ & $5.55 \pm 0.1^{\mathrm{b}}$ & $5.83 \pm 1.44^{\mathrm{b}, \mathrm{c}}$ & $7.3 \pm 0.22^{\mathrm{d}}$ & $25.73 * * *$ \\
\hline
\end{tabular}

Note:Mean \pm standard deviation (SD); ${ }^{*}, \mathrm{p}<0.05,{ }^{* *}, \mathrm{p}<0.01,{ }^{* * *}, \mathrm{p}<0.001$; CSO-Cottonseed oil, GNO-Groundnut oil; Similar superscripts in each row indicate no significant difference at $\mathrm{p}<0.05$.

\section{Total polar components}

Figure 1 shows the total polar components (TPC) of CSO and GNO. TPC increased almost linearly with the frying time similar to that reported by Rani $\boldsymbol{e}$ al.(2010). The initial TPC of GNO and CSO was 3.12 and 4 respectively, which was significantly increased to 7.58 and 14.38 after $25 \mathrm{~h}$ of intermittent frying. Results of both the frying medium, showed increased polar compounds as a result of thermo oxidative transformation during the experimental period of frying Similar results were reported by Raniet al.(2010) and Kimet al.(2008), when Gulab Jamun and wheat flour dough containing egg yolk powder were repeatedly fried in vanaspati and sunflower oil respectively.

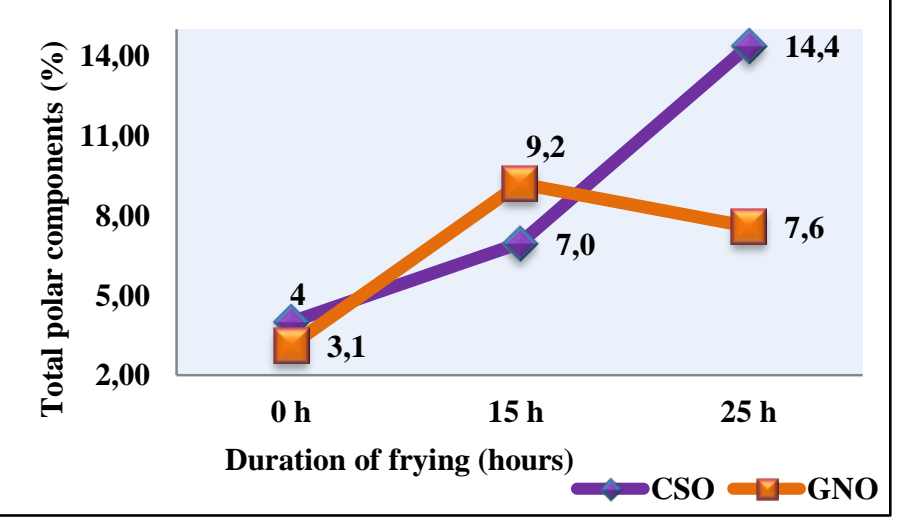

Figure 1Total polar components (TPC) (\%) of CSO (cottonseed oil) and GNO (groundnut oil) at intermittent frying intervals

Note:Values are mean of duplicate values conducted in triplicate

\section{Sensory qualities of bhajias fried in CSO and GNO at different intervals}

Bhajias fried in CSO and GNO at different intervals were assessed for various sensory qualities like appearance, color, crispness, greasiness, flavor, taste, odor and overall acceptability shown in Table 4. F-test showed no significant difference in appearance, color, and crispness of bhajias fried in CSO and GNO. However, color of intermittently fried bhajias increased from 5.9 to 6.3 and 5.6 to 6.3 in CSO and GNO respectively. An insignificant increase was observed in 
greasiness of bhajias fried in CSO. A slight decrease in taste (6.2-5.5) was observed bhajias fried in CSO. Whereas, GNO fried bhajias taste scores decreased from 5.2 to 4.8 at $16 \mathrm{~h}$ interval. Odor and overall acceptability of bhajias fried in GNO showed insignificant increase. Studies have shown no change in sensory qualities of batter coated product fried in different oils (Cunningham et al., 1981; Shih et al., 2009; Mah et al., 2009; Sanz et al., 2008)

Table 4 Sensory attributes of bhajias fried in CSO and GNO at different intervals

\begin{tabular}{|c|c|c|c|c|c|c|c|c|c|c|c|c|c|c|}
\hline \multirow{2}{*}{$\begin{array}{l}\text { Duration of } \\
\text { frying }\end{array}$} & \multicolumn{2}{|c|}{ Appearance } & \multicolumn{2}{|c|}{ Color } & \multicolumn{2}{|c|}{ Crispness } & \multicolumn{2}{|c|}{ Greasiness } & \multicolumn{2}{|c|}{ Taste } & \multicolumn{2}{|c|}{ Odor } & \multicolumn{2}{|c|}{$\begin{array}{c}\text { Overall } \\
\text { acceptability }\end{array}$} \\
\hline & CSO & GNO & CSO & GNO & CSO & GNO & CSO & GNO & CSO & GNO & CSO & GNO & CSO & GNO \\
\hline $\mathbf{0 ~ h}$ & $\begin{array}{c}5.9 \pm \\
1.7\end{array}$ & $\begin{array}{c}5.7 \pm \\
1.6 \\
\end{array}$ & $\begin{array}{c}5.9 \pm \\
1.5 \\
\end{array}$ & $\begin{array}{c}5.6 \pm \\
1.5 \\
\end{array}$ & $\begin{array}{c}5.5 \pm \\
1.7\end{array}$ & $\begin{array}{c}5.1 \pm \\
1.7 \\
\end{array}$ & $\begin{array}{c}5.1 \pm \\
1.3\end{array}$ & $\begin{array}{c}4.9 \pm \\
1.4 \\
\end{array}$ & $\begin{array}{c}6.2 \pm \\
1.9 \\
\end{array}$ & $\begin{array}{c}5.2 \pm \\
1.6 \\
\end{array}$ & $\begin{array}{l}6.1 \pm \\
1.8 \\
\end{array}$ & $\begin{array}{l}5 \pm \\
1.9\end{array}$ & $\begin{array}{c}5.9 \pm \\
1.8\end{array}$ & $\begin{array}{c}5.2 \pm \\
1.4 \\
\end{array}$ \\
\hline $6 \mathrm{~h}$ & $\begin{array}{c}6.1 \pm \\
1.2 \\
\end{array}$ & $\begin{array}{c}6.3 \pm \\
0.9\end{array}$ & $\begin{array}{c}6.5 \pm \\
1.1\end{array}$ & $\begin{array}{c}6.4 \pm \\
1.4\end{array}$ & $\begin{array}{c}5.6 \pm \\
1.7\end{array}$ & $\begin{array}{c}5.4 \pm \\
1.5\end{array}$ & $\begin{array}{c}5.3 \pm \\
1.4\end{array}$ & $\begin{array}{c}5.2 \pm \\
1.4\end{array}$ & $\begin{array}{c}6.5 \pm \\
1.4\end{array}$ & $\begin{array}{c}5.6 \pm \\
1.5\end{array}$ & $\begin{array}{c}6.2 \pm \\
1.1\end{array}$ & $\begin{array}{c}5.7 \pm \\
0.9\end{array}$ & $\begin{array}{c}6.5 \pm \\
1.1\end{array}$ & $\begin{array}{c}5.5 \pm \\
1.4\end{array}$ \\
\hline $11 \mathrm{~h}$ & $\begin{array}{c}6.1 \pm \\
1.3\end{array}$ & $\begin{array}{c}6.1 \pm \\
1.3\end{array}$ & $\begin{array}{c}6.1 \pm \\
1.5\end{array}$ & $\begin{array}{c}6.1 \pm \\
1.4\end{array}$ & $\begin{array}{c}5.6 \pm \\
1.4\end{array}$ & $\begin{array}{c}5.6 \pm \\
1.4\end{array}$ & $\begin{array}{c}4.6 \pm \\
1.4\end{array}$ & $\begin{array}{c}4.5 \pm \\
1.7\end{array}$ & $\begin{array}{c}6.0 \pm \\
1.5\end{array}$ & $\begin{array}{c}5.1 \pm \\
1.2\end{array}$ & $\begin{array}{c}5.6 \pm \\
1.5\end{array}$ & $\begin{array}{c}5.1 \pm \\
0.9\end{array}$ & $\begin{array}{c}6.0 \pm \\
1.5\end{array}$ & $\begin{array}{c}5.3 \pm \\
1.3\end{array}$ \\
\hline $16 \mathrm{~h}$ & $\begin{array}{c}5.6 \pm \\
1.1\end{array}$ & $\begin{array}{c}5.7 \pm \\
1.4\end{array}$ & $\begin{array}{c}5.9 \pm \\
1.2\end{array}$ & $\begin{array}{c}5.9 \pm \\
1.4\end{array}$ & $\begin{array}{c}5.3 \pm \\
1.6\end{array}$ & $\begin{array}{c}5.2 \pm \\
1.5\end{array}$ & $\begin{array}{c}4.0 \pm \\
1.6\end{array}$ & $\begin{array}{c}4.1 \pm \\
1.7\end{array}$ & $\begin{array}{c}5.6 \pm \\
1.4\end{array}$ & $\begin{array}{c}4.8 \pm \\
1.1\end{array}$ & $\begin{array}{c}6.1 \pm \\
1.1\end{array}$ & $\begin{array}{c}4.9 \pm \\
1.5\end{array}$ & $\begin{array}{c}5.5 \pm \\
1.4\end{array}$ & $\begin{array}{c}5.2 \pm \\
1.4\end{array}$ \\
\hline $21 \mathrm{~h}$ & $\begin{array}{c}6.2 \pm \\
1.5\end{array}$ & $\begin{array}{c}6.2 \pm \\
1.6\end{array}$ & $\begin{array}{c}6.3 \pm \\
1.4\end{array}$ & $\begin{array}{c}6.3 \pm \\
1.4\end{array}$ & $\begin{array}{c}6.1 \pm \\
1.4\end{array}$ & $\begin{array}{c}5.6 \pm \\
1.5\end{array}$ & $\begin{array}{c}4.7 \pm \\
2\end{array}$ & $\begin{array}{c}4.4 \pm \\
2.1\end{array}$ & $\begin{array}{c}5.5 \pm \\
2.1\end{array}$ & $\begin{array}{c}5.6 \pm \\
1.0\end{array}$ & $\begin{array}{c}5.4 \pm \\
1.8\end{array}$ & $\begin{array}{c}5.5 \pm \\
1.4\end{array}$ & $\begin{array}{c}5.5 \pm \\
2\end{array}$ & $\begin{array}{c}5.6 \pm \\
1.5\end{array}$ \\
\hline F-value & $0.56^{\mathrm{NS}}$ & $0.91^{\mathrm{NS}}$ & $0.90^{\mathrm{NS}}$ & $1.01^{\mathrm{NS}}$ & $0.71^{\mathrm{NS}}$ & $0.49^{\mathrm{NS}}$ & $2.16^{\mathrm{NS}}$ & $1.36^{\mathrm{NS}}$ & $1.30^{\mathrm{NS}}$ & $1.68^{\mathrm{NS}}$ & $1.05^{\mathrm{NS}}$ & $1.44^{\mathrm{NS}}$ & $1.53^{\mathrm{NS}}$ & $0.40^{\mathrm{NS}}$ \\
\hline
\end{tabular}

Note:Mean \pm standard deviation (SD); NS-non significant; CSO-Cottonseed oil; GNO-Groundnut oil

\section{Oil uptake}

As shown in Table 5 intermittent frying of bhajias in CSO showed $15.6 \%$ oil uptake, whereas GNO fried bhajias showed $19.5 \%$ uptake of oil. Similar results were obtained in a study conducted on legumes and cereal based deep-fried snacks fried in different vegetable oils. Highest oil uptake was observed by peanut oil $(35.9 \%)$ and lowest by cottonseed oil (30.6\%) (Annapure et al 1997). Kitaet al. (2007) revealed that fat absorption is greatly influenced by frying temperature. However, frying at higher temperature $\left(190^{\circ} \mathrm{C}\right)$ in peanut oil decreased the oil uptake in potato crisps.

Table 5 Total oil used after $25 \mathrm{~h}$ of intermittent french fries frying

\begin{tabular}{|c|c|c|c|c|c|c|c|}
\hline Oil & $\begin{array}{l}\text { Initial level of } \\
\text { oil for frying }\end{array}$ & $\begin{array}{c}\text { Total oil } \\
\text { removed for } \\
\text { chemical analysis }\end{array}$ & $\begin{array}{l}\text { Actual amount } \\
\text { of oil used for } \\
\text { frying }\end{array}$ & $\begin{array}{l}\text { Amount of oil left } \\
\text { after } 25 \mathrm{~h} \text { of } \\
\text { intermittent frying }\end{array}$ & $\begin{array}{c}\text { Amount of oil } \\
\text { absorbed (mean) for } \\
25 \text { batches of frying }\end{array}$ & $\begin{array}{c}\text { Amount of oil used } \\
\text { /batch for } 200 \mathrm{~g} \\
\text { bhajias }\end{array}$ & $\begin{array}{c}\% \text { Oil } \\
\text { uptake }\end{array}$ \\
\hline CSO & 1354 & 280 & 1074 & 293.8 & 780.2 & 31.2 & $15.6 \%$ \\
\hline GNO & 1348 & 280 & 1068 & 84.6 & 983.4 & 39.3 & $19.5 \%$ \\
\hline
\end{tabular}

\section{CONCLUSION}

To conclude, during frying thermal-oxidation of GNO and CSO was indicated by alteration in PV and p-AV beyond the acceptable limits. In terms of acid value, iodine value, and 18:2/16:0 (linoleic/palmitic) ratio CSO showed less stability than GNO. Bhajias showed no significant change in sensory qualities when fried intermittently up to $21 \mathrm{~h}$. Bhajias fried in GNO had higher oil uptake as compared to CSO fried bhajias.

Acknowledgments: The authors would like to thank Ankur Oil Industries, Ahmedabad and Potato Research Station, Deesa, Gujarat for providing oil and potatoes for study. The fatty acid profile was carried out at Farelabs, Gurgaon, India.

\section{REFERENCES}

ANNAPURE, U. S., SINGHAL, R. S., KULKARNI, P. R. 1997. Studies on deep-fat fried snacks from some cereals and legumes. Journal of Science and Food Agriculture, 76, 377-82. http://dx.doi.org/10.1002/(sici)10970010(199803)76:3<377::aid-jsfa957>3.0.co; 2 -r

AOAC (Association of Official Analytical Chemists) 1995, Official methods of analysis of the association of official analytical chemists'. $16^{\text {th }}$ edn. ed. Cunniff P. AOCS (Official Methods and Recommended Practices of the American Oil Chemist's Society) 1998, 5th edn., ed. Firestone D. Champaign.

AUGUSTIN, M. A., BERRY, S. K. 1983. Efficacy of the antioxidants BHA and BHT in palm olein during heating and frying. Journal of American Oil and Chemists' Society, 60, 1520-2. http://dx.doi.org/10.1007/bf02666575

CUNNINGHAM, F. E., TIEDE, L. M. 1981. Influence of batter viscosity on breading of chicken drumsticks. Journal of Food Science, 46(6), 1950-52.

FAROOSH, R., MOOSAVI, S. M. R. 2009. Evaluating the performance of peroxide and conjugated diene values in monitoring quality of used frying oils Journal of Agriculture Science and Technology, 11, 173-79.

FIRESTONE, D. 1993. Worldwide regulation of frying fats and oils. Inform, 4, 1366-1371.

HACK, D. M., BORDI, P. L., HESSERT, S. W. J. R. 2009. Nutrition, sensory evaluation, and performance analysis of hydrogenated frying oils. International Journal of Food Science and Nutrition, 1-15. http://dx.doi.org/10.1080/09637480802011128

HAZUKA, Z., PAWLOWICZ, R., TYNEK', M., DROZDOWSKI, B. 2000. Correlation of quality of frying oil and oilextracted from potato fritters fried in liquidand partially hydrogenated rapeseed oils. Journal of Food Lipids, 7, 225 236. http://dx.doi.org/10.1111/j.1745-4522.2000.tb00174.x

HSIA, H. Y., SMITH, D. M., STEFFE, J. F. 1992. Rheological properties and adhesion characteristics of flour-based batters for chicken nuggets as affected by three hydrocolloids. Journal of Food Science, 57(24), 16-18 http://dx.doi.org/10.1111/j.1365-2621.1992.tb05414.x

HUBBARD, L. J., FARKAS, B. E. 2000. Influence of oil temperature on heat transfer during immersion frying. Journal of Food Processing and Preservation, 24, 143-162. http://dx.doi.org/10.1111/i.1745-4549.2000.tb00410.x

JOSHI, V. K. 2006. Methods of sensory analysis. In Sensory science: principles and applications in food analysis. Agrotech Publishing Academy, Udaipur Ch.10, 254-92.

KIM, H., CHOE, E. 2008. Effects of egg yolk powder addition to the flour dough on the lipid oxidation development during frying. LWT-Food Science and Technology, 41, 845-53. http://dx.doi.org/10.1016/i.1wt.2007.05.011

KITA, A., LISINSKA, G., GOLUBOWSKA, G. 2007. The effects of oils and frying temperatures on the texture and fat content of potato crisps. Food Chemistry, 102, 1-5. http://dx.doi.org/10.1016/i.foodchem.2005.08.038

LOEWE, R. 1993. Role of ingredients in batter systems. Cereal Foods World, 38(9), 673-77.

MAH, E., BRANNAN, R.G. 2009. Reduction of oil absorption in deep-fried, battered, and breaded chicken patties using whey protein isolate as a post breading dip: effect on flavor, color, and texture. Journal of Food Science, 74(1), S9-S16. http://dx.doi.org/10.1111/j.1750-3841.2008.00973.x

NARASIMHAMURTHY, K., RAINA, P. L. 1998. Studies on the physicochemical characteristics of some vegetable oils during heating and frying. Journal of Food Science and Technology, 35(5), 432-434.

OGUNSINA, B. S., INDRA, T. N., BHATNAGAR, A. S., RADHA, C. DEBNATH, S., GOPAL, K. A. G. 2011. Quality characteristics and stability of moringa oleifera seed oil of Indian origin. Journal of Food Science and Technology, 51(3), 503-510. http://dx.doi.org/10.1007/s13197-011-0519-5

PASRICHA, S. 2004. Count what you eat. National Institute of Nutrition (ICMR). I ${ }^{\text {st }}$ ed. 33-34.

PATTON, D. 2011. Convenience trend driving demand for coated foods.http://www.foodnavigator.com/Financial Industry/Convenience-trenddriving-demand-for-coated-foods. Accessed on 12 Dec 2011.

PAUL, S., MITTAL, G. S., CHINNAN, M. S. 1997. Regulating the use of degraded oil/fat in deep-fat/oil food frying. Critical Reviews on Food Science and Nutrition, 37 (7), 635-62. http://dx.doi.org/10.1080/10408399709527793

PFA (Prevention of Food Adulteration Act 1954), 2007. Arora K (eds). $17^{\text {th }}$ edn. Professional book publishers, New Delhi, pp 548-560. 
PREMAVALLI, K. S., MADHURA, C. V., ARYA, S. S. 1998. Storage and thermal stability of refined cottonseed oil-mustard oil blend. Journal of Food Science and Technology, 35(6), 530-32.

RANI, A. K. S., REDDY, S. Y., CHETANA, R. 2010. Quality changes in trans and trans free fats/oils and products during frying. European Food Research Technology, 203, 803-811.

SAGUY, I. S., DANA, D. 2002. Integrated approach to deep fat frying: engineering, nutrition, health and consumer aspects. Journal of Food Engineering, 56, 143-52. http://dx.doi.org/10.1016/s0260-8774(02)00243-1

SANZ, T., SALVADOR, A., FISZMAN, S. M. 2008. Performance of three different types of resistant starch in fried battered food. European Journal of Food Research and Technology, 227, 21-27. http://dx.doi.org/10.1007/s00217007-0687-8

SHIH, F.F., BETT-GARBER, K.L., DAIGLE, K.W., INGRAM, D. 2009. Effects of rice batter on oil uptake and sensory quality of coated fried okra. Journal of Food Science, 70(1), S18-S21. http://dx.doi.org/10.1111/j.13652621.2005.tb09058.x

SINGHAL, R. S., BHATTACHARYA, A. B., SAJILATA, M. G., TIWARI, S. R. 2008. Regeneration of thermally polymerized frying oils with adsorbents. Food Chemistry, 110(3), 562-570 http://dx.doi.org/10.1016/j.foodchem.2008.02.033

TYAGI, V. K., SINGH, S. 2001. Deep-fat-frying of Foods-Its significance on nutrition and health. Journal of Food Science and Technology, 38(6), 545-552.

TYNEK', M., HAZUKA, Z., PAWLOWICZ, R., DUDEK, M. 2001. Changes in the frying medium during deep-frying of food rich in proteins and carbohydrates. Journal of Food Lipids, 8, 251-261. http://dx.doi.org/10.1111/j.17454522.2001.tb00200.x

VASISHTHA, A. K., TYAGI, V. K. 1996. Changes in the characteristics and composition of oils during deep-fat frying. Journal of American Oil and Chemists' Society, 73(4), 499-506. http://dx.doi.org/10.1007/bf02523926

ZIAIIFAR, A. M., ACHIR, N., COURTOIS, F., TREZZANI, I., TRYSTRAM, G. 2008. Review of mechanisms, conditions, and factors involved in the oi uptake phenomenon during the deep-fat frying process. International Journal of Food Science Technology, 43, 1410-1423. http://dx.doi.org/10.1111/j.13652621.2007.01664.x 